\title{
DNA Fingerprinting Analysis of Vegetative Compatibility Groups in Aspergillus flavus from a Peanut Field in Georgia
}

\author{
C. E. McAlpin and D. T. Wicklow, Mycotoxin Research Unit, National Center for Agricultural Utilization Re- \\ search, United States Department of Agriculture-Agricultural Research Service (USDA-ARS), Peoria, IL 61604; \\ and B. W. Horn, National Peanut Research Laboratory, USDA-ARS, Dawson, GA 31742
}

\begin{abstract}
McAlpin, C. E., Wicklow, D. T., and Horn, B. W. 2002. DNA fingerprinting analysis of vegetative compatibility groups in Aspergillus flavus from a peanut field in Georgia. Plant Dis. $86: 254-258$

The ability of species-specific DNA probe pAF28 to correctly match 75 strains of Aspergillus flavus isolated from a peanut field in Georgia with 1 of 44 distinct vegetative compatibility groupings (VCGs) was assessed. Multiple strains belonging to the same VCG typically produced identical DNA fingerprints, with the exception of VCG 17 and VCG 24, which contained strains that showed 83 and $87 \%$ similarity, respectively. A. flavus isolates sharing more than $80 \%$ of the fragments are recognized as belonging to the same DNA fingerprint group. Each VCG represented by a single isolate produced unique DNA fingerprints. The results provide further evidence that the pAF28 probe is able to distinguish A. flavus VCGs based on DNA fingerprints and can be used to predict the approximate number of VCGs in a sample population. The DNA probe also hybridized strongly and displayed multiple and distinct bands with other species in Aspergillus section Flavi: A. bombycis, A. caelatus, A. nomius, A. pseudotamarii, and A. tamarii. Although individual strains representing Aspergillus spp. in section Flavi produced DNA fingerprints with multiple bands, the banding patterns could not be used to classify these strains according to species.
\end{abstract}

Additional keywords: Aspergillus bombycis, A. caelatus, A. nomius, A. pseudotamarii, A. tamarii, cluster analysis, corn, DNA profile, restriction fragments

Aspergillus flavus Link:Fr. may infect seed of corn, cotton, peanut, and tree nuts and contaminate them with aflatoxins, which are potent hepatoxic, carcinogenic metabolites that pose a significant health hazard $(3,4)$. Members of Aspergillus section Flavi are widespread in crop fields, particularly in subtropical to tropical latitudes $(5,11,17,19)$. Population biologists seek to understand the genetic structure and diversity of A. flavus populations in crop fields and the distribution of relevant phenotypic characters (e.g., aflatoxin and cyclopiazonic acid production, enzyme production, sclerotium formation, pathogenicity or virulence, competitive ability, and so on) among genetically isolated clonal populations. Vegetative compatibility groupings (VCGs), based on complementation tests between nitrate-nonutiliz-

Corresponding author: C. E. McAlpin

E-mail:mcaplice@mail.ncaur.usda.gov

Names are necessary to report factually on available data; however, the USDA neither guarantees nor warrants the standard of the products, and the use of the name by USDA implies no approval of the product to the exclusion of others that may also be suitable.

Accepted for publication 17 October 2001.

Publication no. D-2001-1220-02R

(C) 2002 The American Phytopathological Society ing (nit) mutants, have been used to examine the genetic diversity of A. flavus populations in an Arizona cotton field $(1,2)$, in a Georgia peanut field $(7,8)$, and in samples of corn grown in Georgia (14). McAlpin and Mannarelli (12) developed what appeared to be a species-specific DNA probe, pAF28, that hybridized strongly only to strains of A. flavus and, based on the DNA fingerprints, was able to correctly distinguish the 22 VCGs among 29 strains of A. flavus reported by Papa (14). The pAF28 probe hybridized to multiple and distinct bands for DNA from different subspecies and cultivars of $A$. flavus (e.g., A. flavus subsp. flavus, A. flavus subsp. parasiticus (Speare) Kurtzman et al., A flavus subsp. flavus var. oryzae (Ahlburg) Kurtzman et al., and $A$. flavus subsp. parasiticus var. sojae (Sakaguchi and Yamada) Kurtzman et al.), but only a single band on a Southern blot with A. nomius Kurtzman et al. This probe subsequently has been used to characterize the genotypic diversity for populations of A. flavus subsp. flavus (20) and A. flavus subsp. parasiticus (13) isolated from a corn field in Illinois.

In the present study, we examined the ability of DNA probe pAF28 to distinguish among 75 A. flavus strains, belonging to 44 VCGs, that were isolated from soil and peanut seed sampled from a peanut field in southwestern Georgia (7). This A. flavus population offers a rigorous test of the probe's ability to distinguish A. flavus strains belonging to different VCGs and thus provides an independent measure of the genetic structure and diversity of the same A. flavus population. Three strains from Papa (14), representing VCGs 6, 14, and 17 detected by Horn and Greene (7), also were examined. It is also important to know if the pAF28 hybridization probe is capable of distinguishing strains representing other Aspergillus spp. in section Flavi: A. tamarii Kita, A. nomius Kurtzman et al., A. caelatus B. W. Horn (6), A. pseudotamarii Ito et al. (9), and A. bombycis Peterson et al. (15).

\section{MATERIALS AND METHODS}

Fungal strains. The A. flavus strains used in this study were obtained from the Agricultural Research Service Culture Collection (National Center for Agricultural Utilization Research, Peoria, IL) and are listed in Table 1. Included in this list are three A. flavus strains isolated from corn grown in Georgia (VCG 6, NRRL 20032; VCG 14, NRRL 20224; and VCG 17, NRRL 20050), representing VCGs first determined by Papa (14). These isolates have been morphologically characterized and their VCG designations determined by complementation tests between nit mutants. Strains representing other species in Aspergillus section Flavi included A. bombycis NRRL 26010 extype and NRRL 25593, A. caelatus NRRL 25528 extype and NRRL 26015, A. nomius NRRL 13137 extype and NRRL 13138, A pseudotamarii NRRL 25517 extype and NRRL 443, and $A$ tamarii NRRL 20818 extype and NRRL 13139. All 75 peanut field isolates were analyzed for DNA fingerprints as part of a "blind study" in which the results of VCG determinations were only provided after DNA fingerprint analyses had been completed. The entire procedure involving DNA isolation, hybridization, detection, and fingerprint analyses was repeated to confirm the DNA profiles of individual fungal strains.

DNA isolation. Mycelia were grown from A. flavus conidial/hyphal suspension $\left(10^{-5} \mathrm{CFU} / \mathrm{ml}\right)$ in $500-\mathrm{ml}$ Erlenmeyer flasks containing $200 \mathrm{ml}$ of yeast extract peptone broth ( $3 \mathrm{~g}$ of yeast extract, $10 \mathrm{~g}$ of peptone, $20 \mathrm{~g}$ of dextrose, 1 liter of distilled water). Following incubation at 200 rpm on a rotary shaker for 22 to $24 \mathrm{~h}$ at 
Table 1. Vegetative compatibility group (VCG) analysis of 75 Aspergillus flavus strains from a peanut field in Georgia and 3 K. E. Papa tester strains from corn

\begin{tabular}{|c|c|}
\hline VCG & Isolates \\
\hline 6 & NRRL $29459,29460,29461,29462,29463,{ }^{\text {a }} 20032^{b}$ \\
\hline 14 & 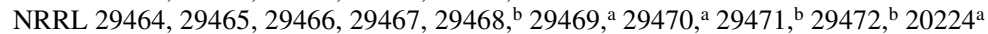 \\
\hline 17 & NRRL $29473,{ }^{\mathrm{b}} 20050^{\mathrm{a}}$ \\
\hline 23 & NRRL 29474, 29475, 29476, 29477, 29478, 29479, 29480 \\
\hline 24 & NRRL 29481, 29483 \\
\hline 25 & NRRL 29487, 29488, b $29489,{ }^{\text {b }} 29490,{ }^{\text {b }} 29491^{\text {b }}$ \\
\hline 26 & NRRL 29492, 29493, 29494, 29495 \\
\hline 27 & NRRL 29496, 29497, 29498 \\
\hline 28 & NRRL 29499, 29500 \\
\hline 29 & NRRL 29501, 29502 ${ }^{\mathrm{b}}$ \\
\hline 30 & NRRL 29503, 29504 \\
\hline 31 & NRRL 29505 \\
\hline 32 & NRRL 29506 \\
\hline 33 & NRRL 29507 \\
\hline 34 & NRRL 29508 \\
\hline 35 & NRRL 29509 \\
\hline 36 & NRRL 29510 \\
\hline 37 & NRRL 29511 \\
\hline 38 & NRRL 29512 \\
\hline 39 & NRRL 29513 \\
\hline 40 & NRRL 29514 \\
\hline 41 & NRRL 29515 \\
\hline 42 & NRRL 29516 \\
\hline 43 & NRRL 29517 \\
\hline 44 & NRRL 29518 \\
\hline 45 & NRRL 29519 \\
\hline 46 & NRRL 29520 \\
\hline 47 & NRRL 29521 \\
\hline 48 & NRRL 29522 \\
\hline 49 & NRRL 29523 \\
\hline 50 & NRRL 29524 \\
\hline 51 & NRRL 29525 \\
\hline 52 & NRRL 29526 \\
\hline 53 & NRRL 29527 \\
\hline 54 & NRRL 29528 \\
\hline 55 & NRRL 29529 \\
\hline 56 & NRRL $29530^{\mathrm{b}}$ \\
\hline 57 & NRRL $29531^{\mathrm{b}}$ \\
\hline 58 & NRRL $29532^{\mathrm{b}}$ \\
\hline 59 & NRRL 29533' \\
\hline 60 & NRRL 29534' \\
\hline 61 & NRRL $29535^{\mathrm{b}}$ \\
\hline 62 & NRRL 29536 \\
\hline 63 & NRRL $29537^{b}$ \\
\hline
\end{tabular}

${ }^{a}$ Isolated from corn grown in Georgia and VCG established by Papa (14); all other VCGs were established by Horn and Greene (7).

${ }^{\mathrm{b}}$ Isolates from peanut seeds. $32^{\circ} \mathrm{C}$, the mycelium was harvested by filtering through a Whatman No. 1 filter paper in a Buchner funnel and rinsed two to three times with sterile distilled water. The mycelial mat was placed in Sarstedt tubes, frozen overnight, and lyophilized for $24 \mathrm{~h}$. DNA was isolated using the method by Raeder and Broda (16) as modified by McAlpin and Mannarelli (12).

DNA hybridization and detection. Total DNA was digested to completion with PST 1 (Roche Molecular Biochemicals, Indianapolis, IN) according to the manufacturer's recommendations. PST 1 was selected as the single enzyme for DNA digestion because it proved superior among five enzymes tested by McAlpin and Mannarelli (12) in distinguishing A. flavus VCGs as determined by Papa (14). Eight microgram of the digested DNA was dispensed in each lane on $0.8 \%$ agarose gel in TAE buffer (0.04 M Tris-acetate, $\mathrm{pH}$ $8.00 ; 0.001 \mathrm{M}$ EDTA ) at $1.5 \mathrm{~V} \mathrm{~cm}^{-1}$ for 22 $\mathrm{h}$ and visualized with UV light after staining with ethidium bromide. Southern blots were performed according to the manufacturer's protocol by transferring restriction fragments from agarose gels to nylon membranes (Nytran N, Schleicher and Schuell, Keene, $\mathrm{NH}$ ) using a vacuum blotter (Model 785; BioRad Laboratories, Hercules, CA). Probes were labeled by random primed labeling and were detected by using the Nucleic Acid Nonradioactive Hybridization System (Roche Molecular Biochemicals). Membranes were exposed to X-ray film (Eastman Kodak, Rochester, $\mathrm{NY}$ ) at room temperature for 30 to $60 \mathrm{~min}$. Several film exposures were made to identify bands of varying intensity.

DNA fingerprint analyses. DNA bands were recorded on the basis of the presence or absence of fragments at a specific position. DNA fragments within each strain were compared by designating and re-

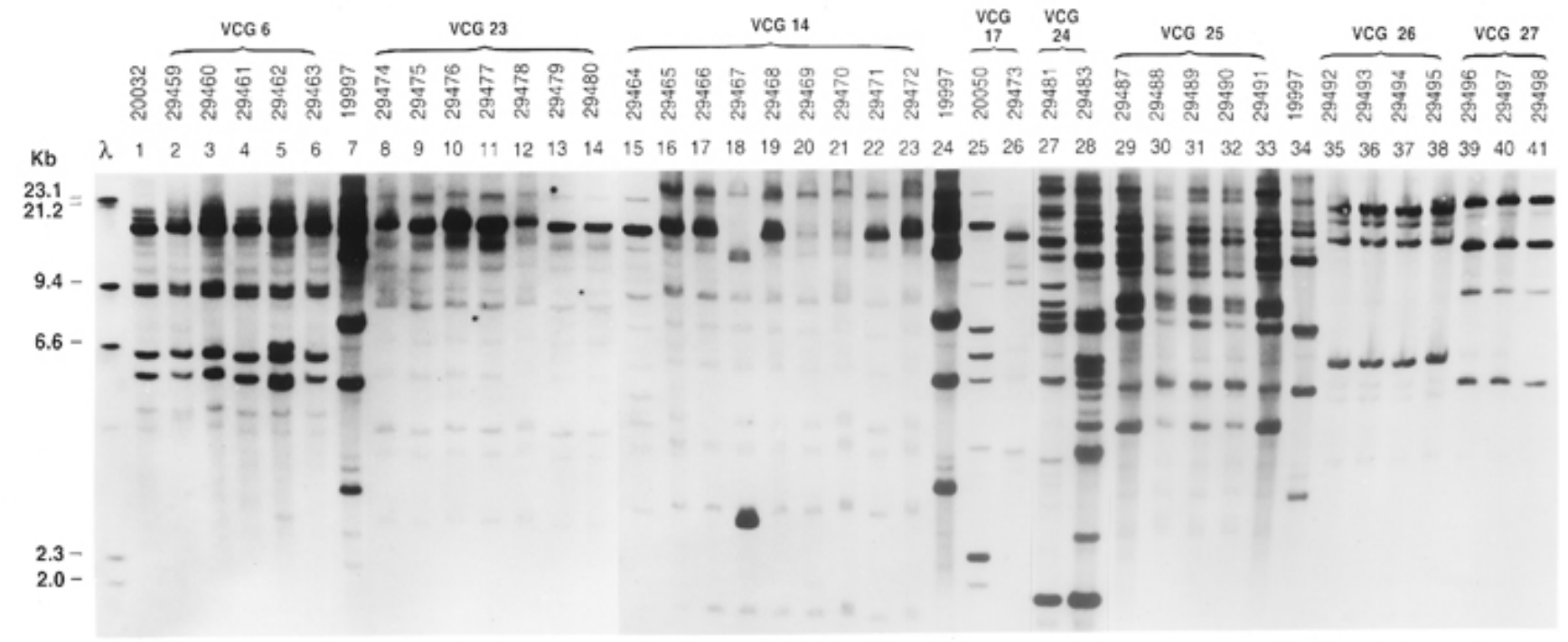

Fig. 1. DNA fingerprints of selected Aspergillus flavus isolates from a Georgia peanut field, two K. E. Papa tester strains from corn (NRRL 20032 and NRRL 20050), a reference strain (NRRL 19997), and size markers. 


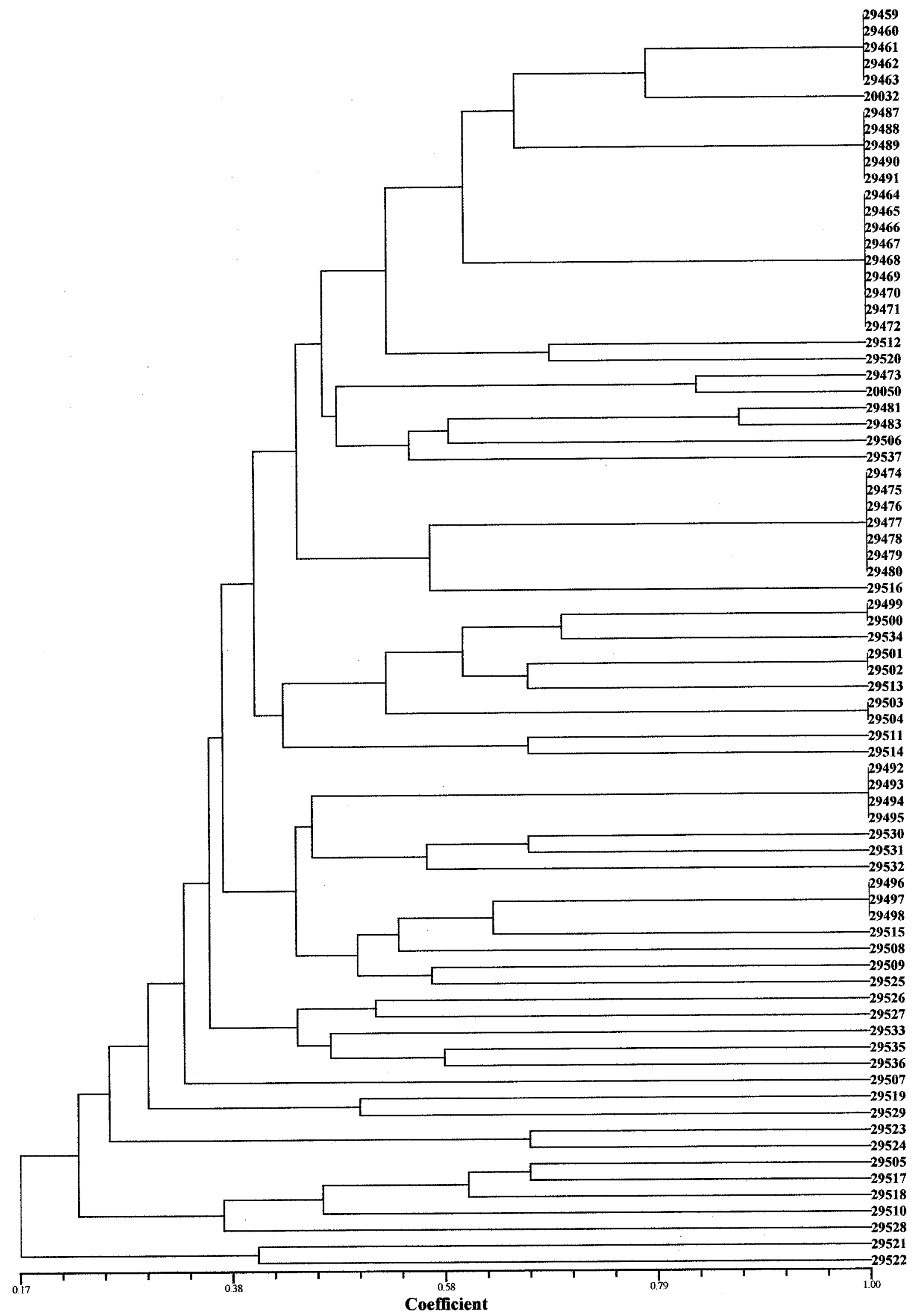

Fig. 2. Phenogram based on cluster analysis of 75 isolates of Aspergillus flavus from a Georgia peanut field and 3 isolates from corn using the Dice similarity coefficient of individual DNA bands produced by hybridization with pAF28 repetitive sequence (12). All isolates belonging to the same vegetative compatibility group are found in the same DNA fingerprint group C > 80\%). The phenogram was generated using the NTSYS-pc ver. 1.8 (18). 
cording 55 fragment positions, representing different molecular weights, with an equidistant marker. Banding patterns produced by different strains were then compared to determine similarity or dissimilarity of fingerprints. Dice similarity coefficients $(C)$ were used to calculate pairwise matching similarity values for each pair of isolates according to the equation $C=2 N x y /(N x+N y)$, in which $N x y$ is the number of hybridizing DNA bands shared by the isolates $x$ and $y$, and $N x$ and $N y$ refer to the number of DNA bands in isolates $x$ and $y$, respectively. The similarity coefficients were used to generate the cluster analysis with SIMQUAL and SAHN programs. The SAHN program determines which strains share identical fingerprints or identifies those belonging to the same fingerprint group, but does not imply phylogenetic relationships. A phenogram was constructed using the Numerical Taxonomy and Multivariate Analysis System (18; NTSYS-pc, ver. 2.01; Exeter Software, Setauket, NY) as generated by the unweighted pair-group arithmetic average (UPGMA) method.

\section{RESULTS AND DISCUSSION}

The species-specific DNA probe pAF28 (12) was able to successfully distinguish among $75 \mathrm{~A}$. flavus strains representing the 44 VCGs reported by Horn and Greene (7) using nit complementation tests. Strains belonging to the same VCG typically produced nearly identical DNA fingerprints (Fig. 1). VCG 6 (lanes 1 to 6) is represented by five peanut field isolates and NRRL 20032 from corn, VCG 23 (lanes 8 to 14 ) is represented by seven peanut field isolates, and VCG 14 (lanes 15 to 23) is represented by nine peanut field isolates. Two fragments of isolate NRRL 29467 (lane 18) showed a slight shift in position. These fragments had strong homology with the probe, judging from the greater band intensity compared with the hybridization patterns of the other isolates in the same VCG. The shift could not be attributed to gel differences because repeated trials showed the same shift in all the gels, but most likely was due to the intensity (strong signal) of the bands.

Several of the peanut isolates produced DNA fingerprints with only one or two major bands while other isolates produced only very faint bands that were difficult to match with other fingerprints. This necessitated repeating the gels, placing isolates adjacent to each other in various combinations, and using longer film exposures for accurate comparisons. Each VCG represented by a single isolate produced unique DNA fingerprints. Two VCGs were represented by isolates with similar, but not identical, DNA profiles sharing more than $80 \%$ of the fragments. These isolates belonged to the same "DNA fingerprint group" according to previously published criteria $(20,21)$. In VCG-17, a peanut field isolate (NRRL 29473) showed $83 \%$ similarity to NRRL 20050 from corn (lanes 25 and 26); and, in VCG 24, two peanut field isolates (NRRL 29481 and NRRL 29483) showed $87 \%$ similarity (lanes 27 and 28) (Fig. 1). Horn and Greene (7) performed two independent experimental pairings of isolates representing VCG 17 , recording a weak but definite line of heterokaryotic heads in seven of the eight plates and a moderately heavy line of heterokaryons in one plate (B. W. Horn, personal communication). The experimental pairing of isolates representing VCG 24 produced a strong and obvious line of heterokaryons and was not repeated. The differences in fingerprints detected for isolates within a VCG could be the result of genetic changes in clonal lineages. Leslie (10) noted that isolates from the same VCG are not always members of the same clone.

The phenetic analysis and phenogram (Fig. 2) compares the DNA banding patterns for 75 peanut field isolates of $A$. flavus (7) and three A. flavus isolates from corn (14). The phenogram shows that strains having identical or similar $(C>$ $80 \%$ ) DNA fingerprint profiles belong to the same VCG. In our previous effort to characterize A. flavus and A. parasiticus populations from a single corn field in Illinois $(13,20)$, we applied the index of genetic similarity for RFLP comparisons after Xia et al. (21). The present results suggest that strains assigned to the same "genotype" or "fingerprint group" in the Illinois populations would also belong to the same VCG.

The DNA probe also hybridized strongly and displayed multiple and distinct bands (Fig. 3), with strains representing other species in Aspergillus section Flavi that have been isolated from peanut fields (e.g., A. caelatus and A. tamarii) or shown to produce aflatoxin (e.g., A. bombycis, A. nomius, and $A$. pseudotamarii). The DNA fingerprints of $A$. bombycis, A. caelatus, A. nomius, A. pseudotamarii, and $A$. tamarii all differed from one another. Within each species, identical DNA fingerprints were

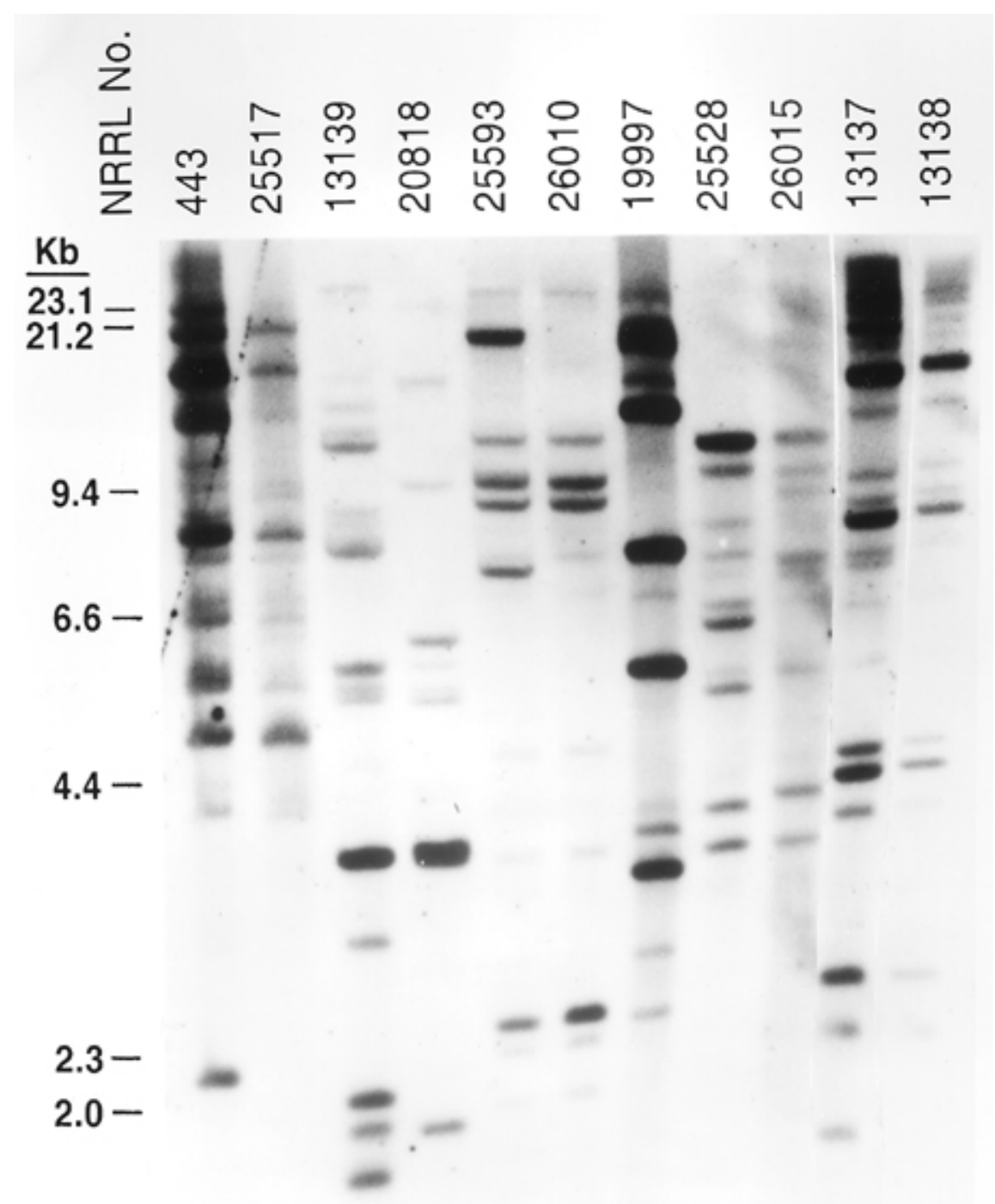

Fig. 3. DNA fingerprints of Aspergillus pseudotamarii (NRRL 443, NRRL 25517 extype), A. tamarii (NRRL 13139, NRRL 20818 ex type), A. bombycis (NRRL 25593, NRRL 26010 extype), A. flavus (NRRL 19997 reference strain), A. caelatus (NRRL 25528 extype, NRRL 26015), and A. nomius (NRRL 13137 extype, NRRL 13138). 
produced by each pair of strains, with the exception of A. tamarii, in which the two strains differed in their fingerprint patterns. Interestingly, the two A. bombycis strains selected for this study were isolated from different silk worm rearing houses in Tokushima prefecture (NRRL 25593) and Kagawa prefecture (NRRL 26010). This genotype may have spread among silk worm rearing facilities from a common source. Individual strains representing Aspergillus spp. in section Flavi produced DNA fingerprints with multiple bands; therefore, the banding patterns could not be used to classify these strains according to species.

The results of this study and those of McAlpin and Mannarelli (12) have shown that DNA fingerprinting using the repetitive DNA probe pAF28 is specific for Aspergillus section Flavi and provides an independent confirmation of the genetic structure and diversity of $A$. flavus populations where all the isolates were initially grouped by VCG analysis $(7,14)$. McAlpin and Mannarelli (12) noted that VCG analysis becomes increasingly cumbersome in studies calling for genetic analysis of large populations because it is necessary to pair each new strain with a representative of each VCG determined for the population. DNA fingerprinting of A. flavus isolates allows us to readily compare new DNA fingerprints with those stored electronically in our data base. It is now possible to more accurately predict that A. flavus isolates belonging to the same pAF28 DNA fingerprint group are also vegetatively compatible.
ACKNOWLEDGMENT

We thank C. Platis for assistance with the analysis of DNA fingerprints.

\section{LITERATURE CITED}

1. Bayman P., and Cotty, P. J. 1991. Vegetative compatibility and genetic variation in the Aspergillus flavus population of a single field. Can. J. Bot. 69:1707-1711.

2. Bayman, P., and Cotty, P. J. 1993. Genetic diversity in Aspergillus flavus: association with aflatoxin production and morphology. Can. J. Bot. 71:23-31.

3. CAST. 1989. Mycotoxins: Economic and Health Risks. Council for Agricultural Science and Technology, Ames, IA.

4. Diener, U. L., Cole, R. J., Sanders, T. H., Payne, G. H., Lee, L. S., and Klich, M. A. 1987. Epidemiology of aflatoxin formation by Aspergillus flavus. Annu. Rev. Phytopathol. 25:249-270.

5. Domsch, K. H., Gams, W., and Anderson, T. 1980. A Compendium of Selected Soil Fungi. Vol. I. and II. Academic Press, New York.

6. Horn, B. W. 1997. Aspergillus caelatus, a new species in section Flavi. Mycotaxon 61:185191.

7. Horn, B., and Greene, R. L. 1995. Vegetative compatibility within populations of Aspergillus flavus, A. parasiticus, and A. tamarii from a peanut field. Mycologia 87:324-332.

8. Horn, B., Greene, R. L., Sobolev, V. S., Dorner, J. W., Powell, J. H., and Layton, R. C. 1996. Association of morphology and mycotoxin production with vegetative compatibility groups in Aspergillus flavus, A. parasiticus, and A. tamarii. Mycologia 88: 574-587.

9. Ito, Y., Peterson, S. W., Wicklow, D. T., and Goto, T. 2001. Aspergillus pseudotamarii, a new aflatoxin producing species in Aspergillus section Flavi. Mycol. Res. 105:233239.

10. Leslie, J. F. 1993. Fungal vegetative compati- bility. Annu. Rev. Phytopathol. 31:127-150.

11. Manabe, M., Tsuruta, O., Tanaka, K., and Matsura, S. 1976. Distribution of aflatoxinproducing fungi in soil in Japan. Trans. Mycol. Soc. Jpn. 17: 436-444.

12. McAlpin, C. E., and Mannarelli, B. 1995. Construction and characterization of a DNA probe for distinguishing strains of Aspergillus flavus. Appl. Environ. Microbiol. 61:10681072.

13. McAlpin, C. E., Wicklow, D. T., and Platis, C. E. 1998. Genotypic diversity of Aspergillus parasiticus in an Illinois corn field. Plant Dis. 82:1132-1135.

14. Papa, K. E. 1986. Heterokaryon incompatibility in Aspergillus flavus. Mycologia 78:98101.

15. Peterson, S. W., Ito, Y., Horn, B. W., and Goto, T. 2001. Aspergillus bombycis, a new aflatoxigenic species from Asia discovered in silkworm frass. Mycologia 93:689-703.

16. Raeder, U., and Broda, P. 1985. Rapid isolation of DNA from filamentous fungi. Lett. Appl. Microbiol. 1:17-20.

17. Raper, K. B., and Fennell, D. T. 1965. The Genus Aspergillus. Williams \& Wilkins Co., Baltimore, MD.

18. Rohlf, F. J. 1997. NTSYS-pc: Numerical Taxonomy and Multivariate Analysis System. Version 2.01. Exeter Software, Setauket, NY.

19. Shearer, J. F., Sweets, L. E., Baker, N. E., and Tiffany, L. H. 1992. A study of Aspergillus flavus/parasiticus in Iowa crop fields: 19881990. Plant Dis. 76:19-22.

20. Wicklow, D. T., McAlpin, C. E., and Platis, C. E. 1998. Characterization of the Aspergillus flavus population within an Illinois maize field. Mycol. Res. 102:263-268.

21. Xia, J. Q., Correll, J. C., Lee, F. N., Marchetti, M. A., and Rhoads, D. D. 1993. DNA fingerprinting to examine microgeographic variation in the Magnaporthe grisea (Pyricularia grisea) in two rice fields in Arkansas. Phytopathology 83:1029-1035. 